\title{
SIGN ORDER IN SLOVENIAN SIGN LANGUAGE LOCATIVE CONSTRUCTIONS ${ }^{* *}$
}

\section{INTRODUCTION}

Cross-linguistically, locative constructions look very much alike, because their word order seems to be dependent on how certain semantic features, namely the size, mobility, and animateness, are valued on participants. Bigger, immobile, and usually nonanimate participants (grounds) that perform spatial anchoring often tend to precede smaller, mobile, and usually animate participants (figures). Therefore, in linguistics, the terms "figure" and "ground" are used to describe the system by which language establishes one participant as a reference point for another participant.

In oral languages, the combination of a spatial adposition with an existential verb is habitually used to encode the relation between the figure and the ground. In sign languages, the existential verb is often not present and spatial information is not necessarily vehiculated by overt spatial adpositions. Instead, the location of the figure with respect to the ground is encoded within a morphologically complex verb sign, which is usually represented by a classifier predicate.

Classifiers in sign languages are meaningful hand configurations that denote a salient characteristic of their referent. They are not independent signs unless combined with a movement subcomponent in order to form classifier predicates. The movement subcomponent of such predicate is said to represent its root, while the handshape (a classifier) is a bound morpheme that may refer back to the participant(s) in the described event. In various sign languages, it has been observed that classifier predicates may influence the constituent order of the transitive sentence. In languages with a basic SVO word order, such as Jordanian (Hendriks 2007), Colombian

* matic.pavlic@ung.si

** This study is based on subsections 7.2 and 7.3 of my doctoral thesis. It was partially supported by the Scholarship for Slovenian Citizens for Postgraduate Study Abroad, number 11010716/2012, COST Action IS1006 Summer School Grant IS1006-060614-044777, and Ca' Foscari internal funds for PhD mobility. The Slovenian Association of Deaf Clubs (Zveza Društev Gluhih in Naglušnih Slovenije, http://www.zveza-gns.si/ helped me to establish and maintain contact with SZJ interpreters (Veronika Ciglar, Natalija Rot, and Natalija Spark) and native deaf signers. For their generous collaboration, I am greatly indebted to my deaf informants Maja Kuzma, Nina and Jan Orešnik, Robert Veršič, and Valerija Škof. I am also grateful to my supervisor Chiara Branchini, my Amsterdam host Roland Pfau, anonymous reviewers, and audience members of FEAST 3 in Venice, SinFonIJA 7 in Graz, SinFonIJA 8 in Ljubljana, and Obdobja 34 in Ljubljana for their kind suggestions and useful comments. All remaining errors are my own. 
(Oviedo 2003), Russian (Kimmelman 2012), and Hong Kong Sign Language, they yield an SOV word order, for example.

In locative constructions, the movement subcomponent of the classifier predicate is modified according to the locations at which the ground and figure are articulated in signing space so that the predicate movement starts in the location where the figure is produced and ends in the location where the ground is produced. In this way, a complex meaning glossed as BE-LOCATED + CL(handshape) is encoded. In SOV sign languages such as Irish (Johnston et al. 2007), Italian (Laudanna 1987), and Sign Language of the Netherlands (Coerts 1994), as well as in SVO sign languages such as American (Liddell 1980), Russian (Kimmelman 2012), Croatian (Milković 2007), Australian, and Flemish (Johnston et al. 2007) Sign Language, locative sentences are reported to display non-basic OSV word order. ${ }^{1}$

In this study, I focus on a locative construction that signers of Slovenian Sign Language (SZJ) use in order to encode a locative relation between two participants. I carefully describe the construction and attempt to determine whether or not its non-basic word order is a result of the effect of a classifier predicate, a locative environment, or both. In section 2, I present the methods of my research. In section 3, I analyse locative constructions in SZJ: firstly, those with classifier predicates (3.1), and then those with non-classifier predicates (3.2). In section 4, I explore locative arguments: the non-manuals accompanying the ground (4.1) and the distributivity of the Figure (4.2). Finally, in section 5, I hypothesise how the surface word order of SZJ locative constructions is derived and revisit the research questions that read as follows:

RQ1 How does SZJ encode locative information: by using a locative adposition within an adposition phrase (as in many oral languages) or by modulating a spatially-agreeing predicate - as in many sign languages?

RQ2 Which types of verbs may represent a predicate in SZJ locative constructions: classifier and/or non-classifier predicates?

RQ3 What is the basic word order in SZJ locative constructions with respect to the type of predicate used?

\section{METHODS}

\subsection{Slovenian Sign Language (SZJ)}

SZJ is the language of the Deaf community in Slovenia. It has received close to no attention by linguists and is also virtually unknown to the majority of Slovenian population. The language is estimated to be used by 900 deaf signers as their primary means

1 For a broader and more detailed introduction to sign language phonology and agreement, see relevant chapters such as "Chapter 8: Classifiers and Chapter" in Sign Languages: A Cambridge Language Survey and "Chapter 12: Word Order", among others, in Sign Languages (Handbooks of Linguistics and Communication Science 37) and the 2012 article "On the Syntax of Spatial Adpositions in Sign Languages" by Roland Pfau and Enoch O. Aboh. 
of communication and by as many as 1600 signers altogether (Vintar et al. 2012). The majority of these deaf signers are at least to some extent familiar with both SZJ and spoken Slovenian.

\subsection{Subjects}

Out of six informants included in my research, three are female and three male. They are L1 deaf signers, ranging in age from 25 to 35, and come from families in which at least one parent is deaf. They are all members of local Deaf clubs and are wellintegrated into the Deaf community. Two of these signers are siblings. All informants collaborated voluntarily and were not paid for their participation. They approved the publication of their data (transcriptions, clips, and stills) for research purposes.

\subsection{Elicitations and Materials}

In eliciting the data, I followed the influential work by Volterra et al. (1984), who first introduced the Picture Description Task (PDT) to sign language studies in order to investigate the word order of Italian Sign Language (LIS). Since they paid special attention to locative constructions, this methodology was especially suitable for my research. Nevertheless, I designed the stimuli (photos and illustrations of still lifes) myself. My informants were shown these stimuli one by one on a computer screen and were asked to describe the depicted situations to the interpreter/deaf co-signer.

\section{LOCATIVE PREDICATION}

In almost all SVO and SOV sign languages for which locative constructions have been studied in detail, it has been discovered that they trigger a non-basic word order as compared to the word order of arguments in transitive sentences. In (1), this is illustrated for an SOV sign language: Sign Language of the Netherlands (NGT; Coerts 1994). In order to describe the situation, the NGT signer articulates the sign TABLE before the sign BALL. Lastly, the relationship among them is set by the classifier predicate, which starts in the location where BALL is produced and ends in the location where the sign TABLE is produced. This yields the OSV word order.

(1) $\mathrm{TABLE}_{\mathrm{A}} \mathrm{BALL}_{\mathrm{B}} \mathrm{B}$ B-LOCATED $+\mathrm{CL}_{\mathrm{A}}$ (Coerts 1994: 65; NGT)

'A/the ball is under a/the table'

(2) Fence CAT SLeEP

(Liddell 1980: 91-100; ASL)

'A/the cat sleeps on a/the fence'

(3) Chair Big CAT IX SiT+CL (Kimmelman 2012: 37; RSL)

'A/the big cat sits on a/the chair'

In example (1), a complex locative meaning is encoded without using any spatial adpositions. Indeed, in the literature on sign languages, it is commonly assumed that 
many sign languages lack spatial adpositions and encode locative information through spatially modified predicates instead. These predicates connect two distinct locations in space by movement and may be modified so that their movement begins in the location at which the figure has been articulated (location ' $\mathrm{B}$ ' in example (1)) and ends in location at which the ground has been articulated (location ' $A$ ' in example (1)). In addition, such a predicate may be represented by a classifier or non-classifier predicate. In (2), for example, the American Sign Language (ASL) signer uses the citation form of the verb "sleep". In the Russian Sign Language (RSL) example (3), on the other hand, the signer uses an agreeing verb SIT + CL articulated with a classifier handshape denoting the type of entity that is seated: namely, a four-legged animal. In fact, cross-linguistically, signers opt for the latter, so that locative predicates tend to be signed with a classifier predicate. Consequently, when researching locative constructions in sign languages, the majority of researchers focus on locative constructions employing classifier predicates, to the exclusion of locative constructions with non-classifier predicates. I believe this is a research gap because, compared to non-classifier predicates, classifier predicates per se may trigger non-basic word orders. In subsection 3.1, I analyse SZJ locative constructions with classifier predicates and compare them to locative constructions with non-classifier predicates in subsection 3.2.

\subsection{Classifier Predicate}

SZJ may encode the spatial location of an entity or an event in various ways. In this section, I present the possibility that was used most frequently and most consistently among my informants. I demonstrate that it is analogous to the locative constructions reported for many other unrelated sign languages, such as American (Liddell 1980), Croatian (Milković et al. 2007), Australian, Flemish, Irish (Johnston et al. 2007), Russian (Kimmelman 2012), and Sign Language of the Netherlands (Coerts 1994). The examples presented below were elicited by the stimulus: a photo that depicts a river with two rows of moored vessels aligned with its left and right bank, respectively. In both examples, the ground (noun phrase RIVER1 or RIVER2) is set first. It is non-manually marked with raised eyebrows. Then the figure (quantified noun phrase MANY VESSEL) is introduced. Finally, the relationship between them is established with a predicate BE-LOCATED + CL(B)+DM. The predicate sign is reduplicated (glossed as DM, distributivity morpheme) in order to denote the number of vessels aligned along the signing space in which the sign RIVER was produced. The word order is ground-figure-predicate.

In SZJ, the noun VESSEL is a two-handed sign, articulated by a b-configuration parallel to the lateral axis. The hands are oriented towards each other and joined at the fingers. They iconically represent the prow of a ship - as in examples (4) and (5). In (6), however, the very same hand configuration is also used for the predicate. Both signs (the noun and verb) are superficially similar with regard to their handshape, but they can easily be set apart by their movement subcomponent. The sign for the noun VESSEL is produced with two repeated circular movements in a given location in space, while the sign for the predicate BE-LOCATED $+\mathrm{CL}(\mathrm{B})$ is produced with one straight short movement ending with a hold in a given location in space. Compare the aforementioned predicate 
with the predicate BE-LOCATED $+\mathrm{CL}(\mathrm{B})$ in examples (4-5). The latter is a one-handed sign produced with the b-configuration, which refers to vehicles in general, while the former was produced as a two-handed sign in a b-configuration, representing vessels in particular. Thus, a set of various different meaningful handshapes can be used in order to produce the predicate sign BE-LOCATED ${ }^{+} \mathrm{CL}$ in (4), (5), and (6). Since verbal classifier systems in both sign and spoken languages generally allow for variability in the choice of a classifier, such that more than one particular verbal classifier may combine with the same verbal root (Slobin et al. 2002 for sign languages, Aikhenvald 2000 for spoken languages), this determines SZJ predicate BE-LOCATED + CL as a classifier predicate.

\section{(4)}
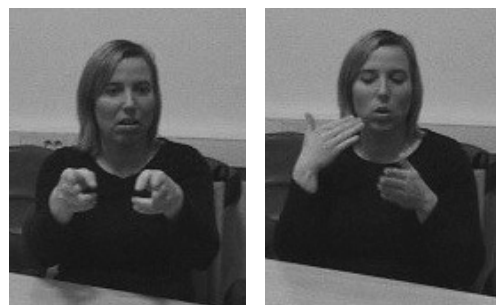

re

${ }_{\mathrm{A}}$ RIVER $1_{\mathrm{B}}$

MANY

'There are many vessels on the river.'

(5)
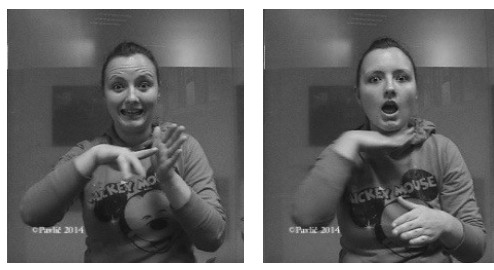

re

${ }_{\mathrm{A}}$ RIVER $2_{\text {в }}$

MANY

'There are many vessels on the river.'
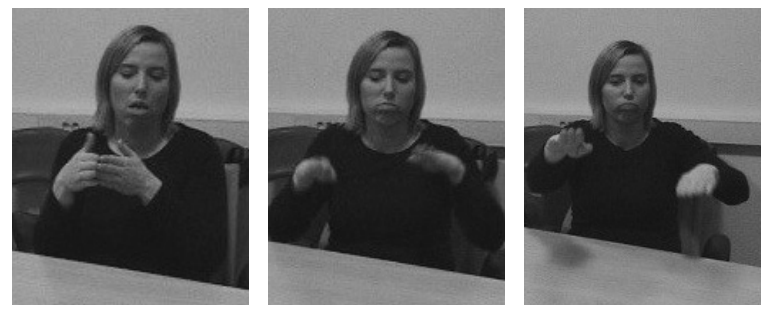

VESSEL

${ }_{\mathrm{A}} \mathrm{BE}-\operatorname{LOCATED}(\mathrm{B})_{\mathrm{B}}+\mathrm{DM}$
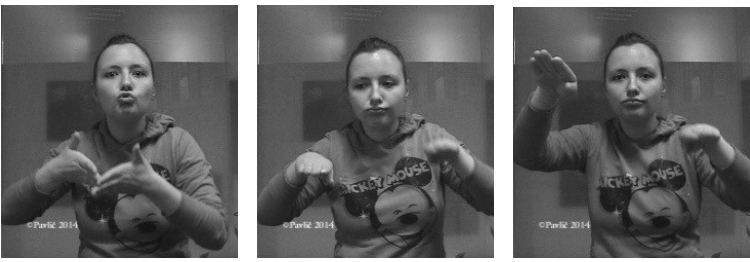

${ }_{\mathrm{A}} \mathrm{BE}-\operatorname{LOCATED}(\mathrm{B})_{\mathrm{B}}+\mathrm{DM}$
VESSEL

\section{(SZJ; loc10n)}

\author{
. \\ .

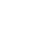 \\ .
}


(6)

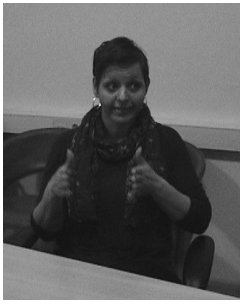

re

${ }_{\mathrm{A}}$ RIVER3
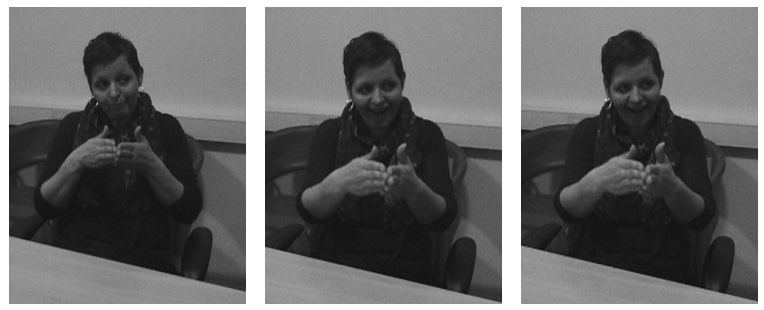

VESSEL
${ }_{\mathrm{A}} \mathrm{BE}-\operatorname{LOCATED}(\mathrm{B}){ }_{\mathrm{B}}+\mathrm{DM}$

'There are (some) vessels on the river.'

(SZJ; v7)

I can now distinguish non-classifier predicates from classifier predicates by employing a simple test. A classifier predicate changes its handshape with respect to certain salient characteristics of the predicated participant, while a lexical verb is not affected in such a way. In the next subsection, I turn to SZJ locative constructions featuring non-classifier predicates.

\subsection{Non-Classifier Predicates}

In this subsection, I examine locative constructions with non-classifier predicates in SZJ. Again, the ground constituent is fronted - similar to locative constructions with a classifier predicate. The figure, on the other hand, is produced only after the predicate contrary to locative constructions with a classifier predicate.

The SZJ verb LAY is a two-handed sign produced in 1-configuration, oriented away from the signer and pointing upwards. During the movement, the arms are fixed, except for the wrists. The wrists hinge, and as the hands move downwards, the fingertips circumscribe an arc movement until they point forward. Since the verb form does not change with respect to the laying participant and since it does not denote its salient characteristics, it is not a classifier predicate, but rather a lexical verb. In example (7), this movement ends in the r-locus where TABLE was previously signed. The sentential structure is different from the one attested in SZJ locative predicates with a classifier predicate. The sentence opens with the ground TABLE, which is in turn followed by the verb LAY and finally ends with the figure POTATO. The word order is ground-predicate-figure. 


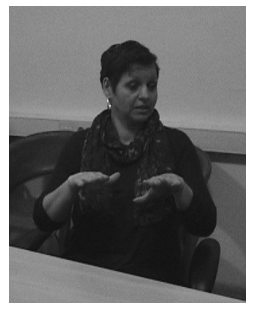

re

TABLE
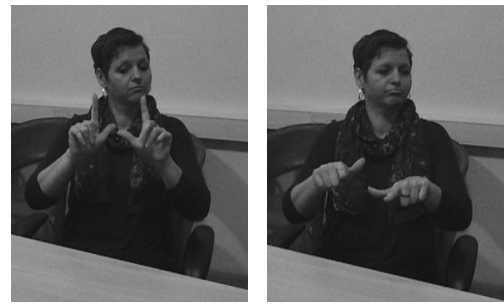

$\left(\frac{10}{10}\right.$

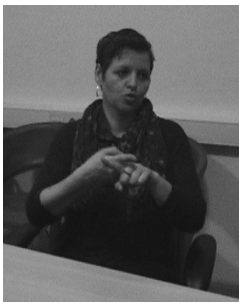

POTATO

'A/the potato lays on a/the table.'

(SZJ; v14)

\subsection{Interim Summary}

In the literature on word order, figures are usually linked to subjects (S), while grounds are linked to objects $(\mathrm{O})$. The figure-ground word order may be compared to the SO word order pattern, while the ground-figure word order may be compared to the OS word order pattern. If we apply it to the SZJ data presented above, we can conclude that the word order in SZJ locative constructions appears to be OSV for classifier predicates and OVS for non-classifier predicates. Note that to compare the correlation pair ground-figure to the correlation pair object-subject does not necessarily mean that figures and grounds indeed take subject and object roles in SZJ locative constructions. I will examine the syntactic functions of the ground and the figure constituent in the next section (4.3).

\section{LOCATIVE ARGUMENTS}

Above, I presented locative constructions with classifier predicates, and I compared them to locative constructions with non-classifier predicates. The former feature an OSV word order, while the latter feature an OVS word order. Both begin with the ground, which is non-manually marked with raised eyebrows. What do raised eyebrows mark? In subsection 4.1, I analyse the ground in SZJ as a constituent that is fronted in non-argumental movement. In subsection 4.2, I use a distributive-morpheme test to demonstrate that figures are base generated as internal arguments.

\subsection{Ground}

In all SZJ locative constructions that I have presented so far, the ground occupied the first position in the clause, regardless of the type of predicate (classifier or non-classifier predicate). In this subsection, I demonstrate that this is a pre-subject position and attempt to determine its category. 
In addition to the canonical locative construction (10), I managed to record a locative predicate with a fronted ground and an agent included in its argument structure. In example (11), the agent BOY takes the subject function and presumably its position in the structure. Therefore, the ground cannot be the subject. At the same time, BOY as a subject marks the left periphery of the clause. Since the ground TABLE precedes the subject, it obviously occupies the left periphery of the clause.
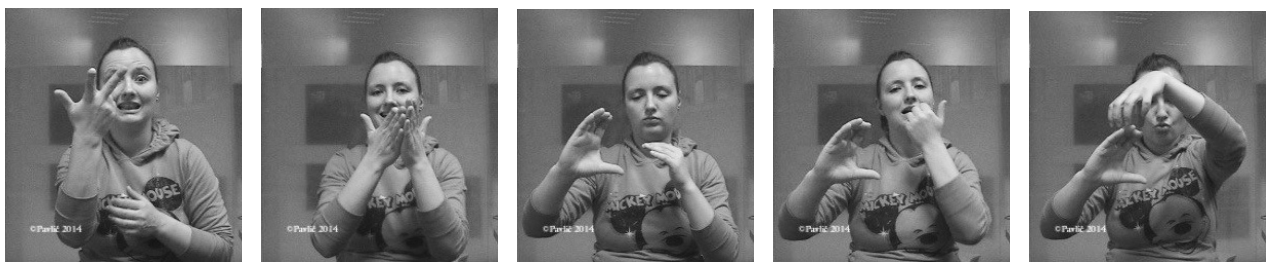

re

THREE BOOK

$\mathrm{CL}(\mathrm{C})_{\mathrm{A}}$

APPLE

BE-LOCATED $(5-B){ }_{\text {A }}$

'There is an/the apple on three books.'

$(\mathrm{SZJ} ; \mathrm{m} 79)$

(11)

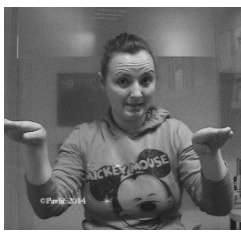

re
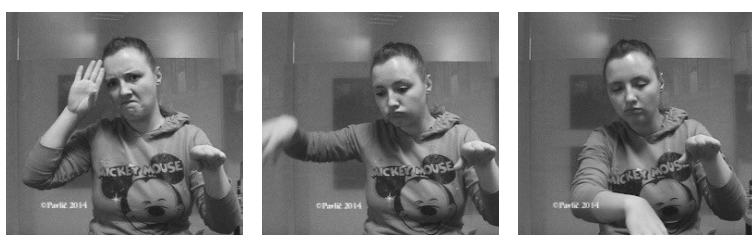

$$
{ }_{\mathrm{A}} \operatorname{PUT}(5-\mathrm{B}){ }_{\mathrm{B}}
$$

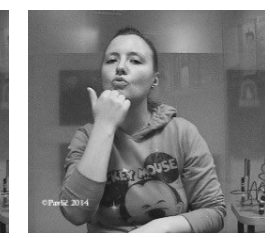

APPLE
(SZJ; m77)

APPLE
(SZJ; m77)

'A boy put an apple under the table.'

Next, I go on to determine the exact type of movement that the ground undergoes. I focus on non-manuals that mark the ground constituent in the clause-initial position. In order to understand the phenomenon, I resort to the cross-linguistic research on information structure in sign languages. Let us examine the minimal pair in (12-13). The signer first signed (13), but immediately corrected herself and suggested (12) as a better variant. She later judged (13) as degraded, but not entirely ungrammatical. The crucial information is marked non-manually. Example (12) represents canonical locative constructions, and in canonical locative constructions, the ground (TABLE) is normally accompanied by 
raised eyebrows. Ground is manually marked by raised eyebrows, presumably because it occupies a non-argumental position within the left periphery. This is further confirmed by a sharp break in signing after the ground is produced. This break is marked by a pause in signing, a blink of the eyes, and the eyebrows suddenly and explicitly returning to the neutral position. Referring to cross-linguistic literature on sign language prosody (Nespor and Sandler 1999; Herrmann 2010; Pfau and Quer 2010; Sandler 2012; Kimmelman 2014; Kimmelman and Pfau 2016), I assume that these markings signal prosodic breaks however, note that SZJ prosody has not been researched at all. I now attempt to determine what kind of movement triggered the displacement of the ground to the left periphery of the sentence. Compare the non-manual behaviour of the figure in examples (12) and (13). In (12), the figure is found in its canonical position with respect to the ground and predicate sign. It is non-manually unmarked. In (13), the figure is not found in its canonical position with respect to the ground and predicate sign: it precedes the ground and is non-manually marked with raised eyebrows. As a result, in (13), both the figure and the ground are marked with the same non-manuals. I assume that they underwent the same type of movement. Since we have already seen in (12) that the ground is fronted through non-argumental movement, I assume that the same holds true for the figure in example (13). However, are the constituents displaced in this movement topicalised or focalised (they are not wh-fronted since the force of the sentences is declarative)?

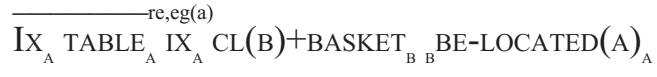

(SZJ; m32b)

'There is a basket on the table.'

$$
\begin{aligned}
& \text { BASKET }_{A} \text { CL(B) B } \text { IX }_{B} \text { TABLE }_{B} \text { AE-LOCATED(A) } \\
& \text { 'There is a basket on the table.' }
\end{aligned}
$$

Rizzi (1997) and a significant body of literature covering various unrelated oral and sign languages have demonstrated that there can only be one focus interpreted in a sentence - contrary to topicalised constituents that have two positions reserved within the left periphery of the clause. Therefore, it seems reasonable to assume that, in (13), the ground and the figure raise each to the specifier position of two distinct topic projections. Furthermore, in both (12) and (13), the ground is endowed with all three of the characteristics that Kimmelman and Pfau (2015) identify as significant for topic constituents in sign languages: (i) as far as the word order is concerned, topics tend to be fronted, (ii) as far as syntactic marking is concerned, topics tend to be marked with raised eyebrows, and (iii) as far as prosody is concerned, topics tend to be followed by a prosodic break. These characteristics are detected in various unrelated sign languages, among others in American (Aarons 1994; Todd 2008), Finnish (Jantunen 2007), Hong Kong (Sze 2008, 2011), Israeli (Rosenstein 2001: ISL), Russian Sign Language (Kimmelman 2012), and in Sign Language of the Netherlands (Coerts 1992; Crasborn et al. 2009). The ground constituents in SZJ locative constructions also display these 
characteristics. Therefore, they are good candidates for topics. However, since topicalisation and the left periphery in general have not been researched in SZJ, the analysis proposed is still pending and its soundness awaits further evidence.

\subsection{Figure}

In this subsection, I apply the distributivity morpheme test to the figure in order to confirm it as an internal argument of SZJ locative constructions. The distributivity morpheme repeats the verb, so that "each repetition of the verb has a start or an end point that is progressively further along the arc of the sweep" in order to "convey the information that the action was performed with respect to each member of the set of entities constituting the subject or object argument" (MacLaughlin et al. 2000: 85-86). According to the same authors, the verb is normally repeated three times, regardless of the number of elements in the set. According to Newman (2012), the distributivity morpheme quantifies over the subject of intransitives or over the object of transitives. This is roughly the same distribution that (i) Pavlič (2016) suggests for the distributive morpheme in SZJ and that (ii) Benedicto and Brentari (2004) suggest for the distributive morpheme in American Sign Language. Since in both languages distributive morphemes only attach to those verbs that license an internal argument, the distributive morpheme may be used as a test to verify the presence of an internal argument in these languages.

Let me return to the "vessel examples" above. In (4) and (5), a total of six repetitions of the verb are divided into two sets, so that the verb is repeated three times "progressively further along" the right bank and three times "progressively further along" the left bank. These six repetitions form two distributive morphemes. Since distributive morphemes attach exclusively to predicates that license an internal argument, I conclude that the figure functions as an internal argument in classifier-predicate examples (4), (5), and (6). A similar pattern may be observed in SZJ locative constructions with a lexical verb, such as LAY in (7). Again, according to the grammaticality judgments of my informants, the predicate may reduplicate (14). Thus, according to the distributivity-morpheme test, figures are base generated in the internal argument position.

(14)
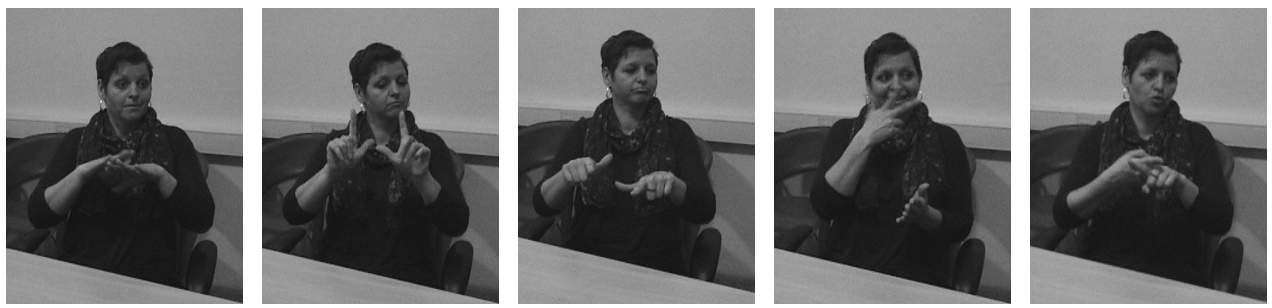

TABLE

LAY+DM
THREE

POTATOE

'Three potatoes are lying on a/the table.'

(SZJ; loc-gjt4) 
Finally, there is also the difference in word order between classifier and nonclassifier predicates with respect to the figure. Is it the verb that moves in one case, but not in the other? Or is it actually the figure that moves from its base position with classifier predicates, but not with lexical predicates? Indeed, the effect of a classifier predicate on the word order in transitive and locative sentences is a well-known phenomenon in sign language linguistics, but in these two environments, the constituents themselves do not necessarily provide enough information about their relative position in the syntactic structure. Independent and at the same time indirect evidence derives from SZJ ditransitives (Pavlič 2016), in which the classifier predicate is found between the direct and the indirect object, yielding a non-basic $\mathrm{SO}_{\mathrm{d}} \mathrm{VO}_{\mathrm{i}}$ word order (as compared to basic $\mathrm{SVO}_{\mathrm{d}} \mathrm{O}_{\mathrm{i}}$. displayed in SZJ ditransitives with a non-classifier predicate). This position seems to suggest that, in SZJ, classifier predicates do not move to higher sentential projections. In future research on SZJ, this tentative explanation must be confirmed by standard dominance tests, such as quantifier scope or anaphora binding.

\section{CONCLUSION}

In this research, I examined the morpho-syntactic properties of the predicates in locative constructions of Slovenian Sign Language (SZJ), as well as the syntactic functions of the figure and ground constituents. This enabled me to determine the surface word orders that are attested in the examples I provided. The ground appears as the first constituent in SZJ locative constructions, regardless of the type of predicate. The type of predicate, in turn, does influence the word order. I assume that the classifier predicate remains in situ, yielding a ground-figure-predicate (OSV) word order, while the lexical verb moves to higher sentential projections, yielding a ground-predicate-figure (OVS) word order. This answers research questions RQ1 - RQ3:

A1 SZJ encodes locative information by modulating a spatially-agreeing predicate.

A2 In SZJ locative constructions, a classifier predicate, a lexicalised classifier predicate, and a lexical verb may all encode a predicate.

A3 The basic word order in SZJ locative constructions is OSV when a classifier predicate is used and is OVS when a lexicalised classifier predicate or a lexical verb is used.

\section{References}

AARONS, Debra (1994) Aspects of the Syntax of American Sign Language. Ph.D. Thesis. Boston University, Boston.

BENEDICTO, Elena/Diane BRENTARI (2004) "Where Did All the Arguments Go? Argument-Changing Properties of Classifiers in ASL." Natural Language and Linguistic Theory 22/4, 743-810. 
COERTS, Jane (1992) Nonmanual Grammatical Markers: An Analysis of Interrogatives, Negations and Topicalisations in Sign Language of the Netherlands. Ph.D. Thesis. University of Amsterdam, Amsterdam.

COERTS, Jane (1994) "Constituent Order in Sign Language of the Netherlands and the Functions of Orientations." In: I. Ahlgren/B. Bergman/M. Brennan (eds), Perspectives on Sign Language Structure. Durham: ISLA, 69-88.

COMRIE, Bernard (1989) Language Universals and Linguistic Typology. Oxford: Blackwell.

CRASBORN, Onno/Els V. der KOOIJ/Johan ROS/Helen de HOOP (2009) "Topic Agreement in NGT (Sign Language of the Netherlands)." The Linguistic Review 26, 355-370.

CULICOVER, Peter/Robert LEVINE (2001) "Stylistic Inversion in English: A Reconsideration." Natural Language \& Linguistic Theory 19, 283-310.

JANTUNEN, Tommi (2007) "On Topic in Finnish Sign Language." Unpublished Ms.

JOHNSTON, Trevor/Myriam VERMEERBERGEN/Adam SCHEMBRI/Lorraine LEESON (2007) "Real Data are Messy: Considering Cross-Linguistic Analysis of Constituent Ordering in Auslan, VGT, and ISL." In: P. Perniss/R. Pfau/M. Steinbach (eds), Visible Variation: Comparative Studies on Sign Language Structure. Berlin: Mouton de Gruyter, 163-205.

HERRMANN, Annika (2010) "The Interaction of Eye Blinks and Other Prosodic Cues in German Sign Language." Sign Language and Linguistics 13/1, 3-39.

KIMMELMAN, Vadim (2012) "Word Order in Russian Sign Language." Linguistics in Amsterdam, 1-56.

KIMMELMAN, Vadim (2014) Information Structure in Russian Sign Language and Sign Language of the Netherlands. Amsterdam: Amsterdam Center for Language and Communication (ACLC).

KIMMELMAN, Vadim/Roland PFAU (2016) "Information Structure in Sign Languages." In: C. Fery/S. Ishihara (eds), The Oxford Handbook on Information Structure. Oxford: Oxford University Press, 814-835.

LAUDANNA, Alessandro (1987) “Ordine dei segni nella frase." In: V. Volterra (ed.), La Lingua Italiana dei Segni. Bologna: Il Mulino, 211-230.

LAUDANNA, Alessandro/Virginia VOLTERRA (1991) "Order of Words, Sign and Gestures: A First Comparison." Applied Psycholinguistics 12, 135-150.

LIDDELL, Scott K. (1980) American Sign Language Syntax. Hague: Mouton Publishers. MACLAUGHLIN, Dawn/Carol NEIDLE/Benjamin BAHAN/Robert. G. LEE (2000) "Morphological Inflections and Syntactic Representations of Person and Number in ASL." Recherches linguistiques de Vincennes 29, 73-100.

MATHUR, Gaurav/Christian RATHMANN (2012) "Verb Agreement." In: R. Pfau/M. Steinbach/B. Woll (eds), Sign Languages. Berlin/Boston: Mouton De Gruyter, 136-157.

MILKOVIĆ, Marina/Sandra BRADARIĆ-JONČIĆ/Ronie B. WILBUR (2007) "Information Status and Word Order in Croatian Sign Language." Clinical Linguistics and Phonetics 21/11-12, 1007-1017. 
NESPOR Marina/Wendy SANDLER (1999) "Prosody in Israeli Sign Language." Language and Speech: Special Issue on Prosody in Spoken and Signed Languages $42(2 / 3), 143-176$.

NEWMAN, Paul (2012) "Pluractional Verbs: An Introduction." In: P.C. Hofherr/B. Laca (eds), Verbal Plurality and Distributivity. De Gruyter, 185-211.

PADDEN, Carol. (1983) Interaction of Morphology and Syntax in American Sign Language. Ph.D. Thesis, University of California, San Diego.

PAVLIČ, Matic (2016) The Word Order Parameter in Slovenian Sign Language: Transitive, Ditransitive, Classifier and Locative Constructions. Ph.D. thesis. Ca' Foscari, Venice.

PERNISS, Pamela/Roland PFAU/Markus STEINBACH (2007) "Can't You See the Difference? Sources of Variation in Sign Language Structure.” In: P. Perniss/R. Pfau/M. Steinbach (eds), Visible Variation: Comparative Studies on Sign Language Structure. Berlin: Mouton de Gruyter, 1-34.

PFAU, Roland/Joseph QUER (2010) "Nonmanuals: Their Grammatical and Prosodic Roles." In: D. Brentari (ed.), Cambridge Language Surveys: Sign Languages. Cambridge: Cambridge University Press, 381-402.

DE QUADROS, Ronice Müller/Joseph QUER (2008) "Back to Back(wards) and Moving On: On Agreement, Auxiliaries and Verb Classes in Sign Languages." In: R.M. De Quadros (ed.), Sign Languages: Spinning and Unraveling the Past, Present and Future. Petrópolis/RJ, Brazil: Editora Arara Azul, 530-551.

RIZZI, Luiggi (1997) "The Fine Structure of the Left Periphery.” In: L. Haegeman (ed.), Elements of Grammar. Dordrecht: Kluwer, 281-337.

ROSENSTEIN, Ofra. (2001) ISL as a Topic-Prominent Language. Master's Thesis. University of Haifa.

SANDLER, Wendy (2012) "Visual Prosody." In: R. Pfau/M. Steinbach/B. Woll (eds), Sign Language. Berlin/Boston: Mouton De Gruyter, 50-76.

SZE, Felix. Y. B. (2008) Topic Constructions in Hong Kong Sign Language. Ph.D. Thesis. University of Bristol.

SZE, Felix. Y. B. (2011) "Nonmanual Markings for Topic Constructions in Hong Kong Sign Language." Sign Language \& Linguistics 14/1, 115-147.

TALMY, Leonard (2000) Toward a Cognitive Semantics. Cambridge, MA: MIT Press.

TODD, Peyton (2008) “ASL Topics Revisited.” Sign Language \& Linguistics 11/2, 184-239.

VOLTERRA, Virginia/Alessandro LAUDANNA/Serena CORAZZA/Elena RADUTZKY/Francesco NATALE (1984) "Italian Sign Language: The Order of Elements in the Declarative Sentence." In: F. Loncke/P. Boyes-Braem/Y. Lebrun (eds), Recent Research on European Sign Languages. Lisse: Swets and Zeitlinger, $19-48$. 


\section{Summary \\ SIGN ORDER IN SLOVENIAN SIGN LANGUAGE LOCATIVE CONSTRUCTIONS}

In both sign and spoken languages, locative relations tend to be encoded within constructions that display the non-basic word/sign order. In addition, in such an environment, sign languages habitually use a distinct predicate type - a classifier predicate - which may independently affect the order of constituents in the sentence. In this paper, I present Slovenian Sign Language (SZJ) locative constructions, in which (i) the argument that enables spatial anchoring ("ground") precedes both the argument that requires spatial anchoring ("figure") and the predicate. At the same time, (ii) the relative order of the figure with respect to the predicate depends on the type of predicate employed: a non-classifier predicate precedes the figure, while a classifier predicate only comes after the figure.

Keywords: locative construction, locative adposition, figure and ground, classifier predicate, Slovenian Sign Language

\section{Povzetek \\ ZNAKOVNI RED V KRAJEVNIH IZRAZIH SLOVENSKEGA ZNAKOVNEGA JEZIKA}

V krajevnih stavkih sestavniki pogosto sledijo besednemu/znakovnemu redu, ki ni v skladu z osnovnim besednim/znakovnim redom danega govornega oziroma znakovnega jezika. Poleg tega je za znakovne jezike značilno, da se v tem skladenjskem okolju pojavlja poseben tip predikata (klasifikatorski predikat), ki že sam zase lahko vpliva na zaporedje sestavnikov $\mathrm{v}$ stavku. $\mathrm{V}$ članku predstavljam krajevne stavke slovenskega znakovnega jezika (SZJ). V njih je (i) argument, ki predstavlja referenčno točko ('podlaga'), umeščen pred argument, ki potrebuje referenčno točko ('lik'), in predikat; medtem ko je (ii) zaporedje lika in predikata odvisno od vrste predikata: ne-klasifikatorski predikat se umešča pred lik, klasifikatorski predikat pa za lik.

Ključne besede: krajevni stavki, krajevni predlogi, lik in podlaga, klasifikatorski predikati, slovenski znakovni jezik 